\title{
Donald J. Trump: Jacksonian Minoritarian?
}

\section{Thomas J. Cobb}

Coventry University

\begin{abstract}
The label of the 'Jacksonian' has served to add a sense of definition and historical precedent to a seemingly anomalous presidency. Comparisons between Donald Trump and President Andrew Jackson (the progenitor for the Jacksonian creed) have hinged on the perception that the Jacksonian philosophy purveys belief in majoritarian nationalism, diplomatic realism and the preeminence of America's white male labouring class. Commentators as diverse as New York Times journalists and International Relations theorists have applied such readings.

Through investigating the changing paradigms of the Jacksonian, from its incipience in the 1820s to its ascription in Trump's populism, this article underlines how its shibboleths have gradually shifted towards becoming part of a 'minoritarian' phenomenon. Trump's victory in the 2016 presidential election, which was achieved in spite of his loss of the popular vote and failure to win former Republican states such as Virginia, indicated that the Jacksonian resurgence perceived in this contest was heavily dependent on the economic decline of the industrial Midwest. This contrasts with the cooption of the Jacksonian under FDR and Ronald Reagan, whose first terms resulted from comprehensive national landslides.

Because of this lack of broader support, Trump's affinity with a decreasing population of white male non-college educated voters forms the existential driver of his presidency. Conveying a reversal of Andrew Jackson's majoritarianism, my research highlights that Jacksonian survival now hinges on consolidating the kind of minoritarian influence implied by the results of the 2016 presidential election. This analysis, along with my historiography of the Jacksonian, establishes the changes undergone by this significant American ideology.
\end{abstract}

Keywords: Donald Trump, Andrew Jackson, Jacksonianism, majoritarian nationalism, populism

Since Trump's participation in the Republican primaries in early 2016 and especially after the 2016 presidential election, the invocation of President Andrew Jackson and the corollary label of the 'Jacksonian' have added a 
sense of precedent to a seemingly anomalous political figure. Numerous academics and journalists have argued that Jackson's identity and tenure can be viewed as a model for Trump's presidency.

In January 2016, the International Relations theorist Walter Mead observed that Trump's popularity amongst Republican primary voters meant the return of "Jacksonian populism" and that Andrew Jackson was again "central in American political life."1 Only a few days after Trump's celebratory address to the New York Hilton Midtown, Mead interpreted this resurgence further and posited that "Mr. Trump's strongest supporters are the $21^{\text {st }}$-century heirs of a political tendency that coalesced in the early $1820 \mathrm{~s}$ around Andrew Jackson." 2 The president-elect's successful appeal to this heritage, reflected in disdain towards the "Democratic support for identity politics among every group in the country except for heterosexual white males", proved to Mead that "Andrew Jackson is still the most important figure in American politics". ${ }^{3}$

Nine months later, the military historian Andrew Bacevich invoked the “crude Andrew Jackson's 1828 ousting of an impeccably pedigreed president" to indicate 2016's transformative quality. Trump's ambition of ending a "post-Cold War consensus" meant that Jackson's defeat of John Quincy Adams "was nothing compared to the vulgar Donald Trump's defeat of an impeccably credentialed graduate of Wellesley and Yale who had served as first lady, United States senator, and secretary of state." 4

In terms of the American journalists who outlined Trump's presidency as updated Jacksonianism, a January 2017 article by Jonah Engel Bromwich of The New York Times defined Trump as "natural successor to Andrew Jackson, America's architect of political populism". ${ }^{5}$ More recently in 2019, Jamelle Bouie heightened this lineage by citing a "particularly virulent form of reactionary white majoritarianism", stemming from the presi-

1 Walter Russell Mead, “Andrew Jackson, Revenant," The American Interest, January 17, 2016, https:// www.the-american-interest.com/2016/01/17/andrew-jackson-revenant/.

2 Walter Russell Mead, "Donald Trump's Jacksonian Revolt," Hudson Institute, November 13, 2016, https:// www.hudson.org/research/13010-donald-trump-s-jacksonian-revolt.

3 Ibid.

4 Andrew Bacevich, “Trump Is Not the Problem," The Nation, August 8 2017, https:/www.thenation .com/ article/trump-is-not-the-problem/.

5 Jonah Engel Bromwich, "The Wild Inauguration of Andrew Jackson, Trump's Populist Predecessor," The New York Times, Jan 20, 2017, https://www.nytimes.com/2017/01/20/us/politics/donald-trump-andrewjackson.html. 
dent "channeling his hero, Andrew Jackson". ${ }^{6}$ Perhaps, however, the most obvious propagator of the Jacksonian leitmotif has been Trump himself, a connection indicated when he praised Andrew Jackson's foresight and passion in a May 2017 interview with the Washington Examiner Reporter Saleno Zita. $^{7}$

In this article, I assess the congruency of Trump's Jacksonianism with the political mores of Andrew Jackson's presidency. I consequently highlight how the amorphousness of the Jacksonian label elides specificity and a concentrated account of this complex political doctrine's minoritarian status under Trump. The need for this redress is emphasized through inspection of the realities of the 2016 election, which revealed a Jacksonian demographic lacking the hegemony of earlier generations.

I begin with an examination of the Jacksonian culture and politics incarnated in the 1820s, followed by a historiography of Andrew Jackson's impact on both the modern Democratic and Republican parties. The article proceeds to argue that Trump's presidency renders a Jacksonianism 'minoritarian' in character and shorn of the comprehensive electoral sweep it possessed in the early nineteenth century. I then conclude that definitions of the Jacksonian, as applied by writers as diverse as Mead and New York Times journalists, are too heterogeneous. More rigorous forms of categorization, along with an understanding of how conceptions of Jacksonianism have changed with the passage of time, should qualify comparisons between Trump and Andrew Jackson.

\section{The origins of Jacksonianism and its political legacy}

Andrew Jackson was born in the Waxhaw region straddling the North and South Carolina border to a Scots-Irish family. ${ }^{8}$ These backcountry origins later contrasted with Jackson's adulthood in the state of Tennessee, where he forged a successful legal and military career. ${ }^{9}$ It was the latter of these vocations which most occupied Jackson's attention and offered the

6 Jamelle Bouie, “Trump's Trail of Fears," The New York Times, February 11, 2019, https://www.nytimes. com/2019/02/11/opinion/trump-warren-trail-tears.html.

7 Associated Press website, "Trump quotes about Andrew Jackson and the Civil War," May 1, 2017, https:// www.apnews.com/bda98d6b52c54ac6954e400c5e822d1f.

8 Sean Wilentz, Andrew Jackson: The American Presidency Series (New York, New York: Henry Holt and Company, 2005), 15.

9 Ibid, 19-21. 
fame requisite for a presidential candidate. His ascent to national icon first stemmed from his victory as a general in the January 1815 Battle of New Orleans, a climax to the War of 1812 which Tregle contended formed an "overwhelming factor in bringing Andrew Jackson to the presidency" and promptly initiated what Phillips describes as the "superficial harmony" of the Era of Good Feelings. ${ }^{10}$ Jackson's political rise between his military triumph in 1815 and his election in 1828, however, hinged on the declining image of consensus contrived by Democratic-Republican Presidents James Monroe and John Quincy Adams.

Early signs of Jackson's relationship with the fracturing of the dominant Democratic-Republican regime emerged in the spring of 1818. The general's expulsion of the Spanish from Florida incurred splits within the Monroe administration. President Monroe took an equivocal position between the views of his Secretary of War John C. Calhoun and Secretary of State John Quincy Adams, who respectively demanded censure of and endorsement for Jackson. ${ }^{11}$ The panic of 1819 , a financial crisis thought to have been a consequence of excessive speculation in public lands, furthered Jackson's independence from Monroe and elicited a reputation for antielitism. Jackson commented that "habits of extravagance and of transacting business too much upon credit" should prompt the return of "former habits of industry and simplicity". ${ }^{12}$

These formations of political identity did not stop Jackson's campaign in the 1824 election from promising to continue the "American System" of economic nationalism propounded by contemporaneous Speaker of the House and fellow presidential candidate Henry Clay. ${ }^{13}$ Nevertheless, this election played a transformative role for Jackson's image as a pugnacious outsider.

10 Joseph G. Tregle Jr., “Andrew Jackson and the Continuing Battle of New Orleans," Journal of the Early Republic 1, no. 4 (Winter 1981): 373; Kim T. Phillips, "Democrats in the Old School in the Era of Good Feelings," The Pennsylvania Magazine of History and Biography 95, no. 3 (July 1971): 363.

11 Stephen Skowronek, The Politics Presidents Make: Leadership from John Adams to Bill Clinton (Cambridge, Massachusetts: Belknap Press, 1997), 94.

12 Daniel Feller, The Jacksonian Promise: America, 1815-1840 (Baltimore, Maryland: The Johns Hopkins University Press, 1995), 43.

13 Ibid, 66-67. Feller details how 1824 candidates William Henry Crawford, Henry Clay, Andrew Jackson and John Quincy Adams were "championed, at least where such views were popular, as friends of home manufacturing and internal improvement." He notes, "In a public letter Jackson acclaimed protection as a prescription for national independence and touted the power of the federal government to 'give a proper distribution to our labor.", 
Overwhelmingly decisive in catalyzing the Jacksonian call for what William Nelson defines as the "institutions of majoritarian democracy" was the perverse outcome of the contest rather than any policy differences between its contestants. ${ }^{14}$ Jackson's popular vote total exceeded runner up John Quincy Adams by more than ten percentage points, but the sectional nature of the contest meant that none of the four candidates who ran for president possessed a majority in the Electoral College. The resolution of the election in the House of Representatives, an elective body led by Henry Clay and dominated by an anti-Jackson majority, enabled Adams to take the presidency. Adams' nomination of Clay as Secretary of State in 1825 compounded accusations of elitism and facilitated the idea that his presidency had resulted from a 'corrupt bargain'.

Trends which had accelerated the participation of white males in the voting process made Adams's minority presidency additionally incongruous. According to Sean Wilentz, twenty-one of the twenty-four states present by 1821 "had approved something approaching a divorce of property-holding and voting" for white men wishing to vote in statewide races. ${ }^{15}$ This enfranchisement occurred alongside a "highly uneven pattern of democratization", as "five of the original thirteen states" had "either withdrawn or sharply curtailed black voting rights" while only six Northern states allowed manhood suffrage for "blacks as well as whites". ${ }^{16}$

The process of democratization in statewide races was approximately mirrored in the 1824 presidential election, where "eighteen out of twentyfour states gave the choice of Electors to the people", a change from the formerly comprehensive 1790s practice of awarding electoral votes through state legislatures. ${ }^{17}$ Although Jackson won the support of two Southern states where state legislatures still superseded white male suffrage, South Carolina and Louisiana, his aggregate vote amongst the eighteen 'democratized' states resulted in a plurality which enabled an anti-elitist platform against John Quincy Adams in $1828 .{ }^{18}$ Helped by the coalition building

14 William E. Nelson, The Roots of American Bureaucracy: 1830-1900 (Washington D.C.: Harvard University Press, 1982), 41.

15 Sean Wilentz, The Rise of American Democracy: Jefferson to Lincoln (New York: W.W. Norton \& Company, 2005), 201.

16 Ibid, 201.

17 Donald Ratcliffe, "Popular Preferences in the Presidential Election of 1824," Journal of the Early Republic 34, no. 1 (Spring 2014): 67.

18 Ibid, 67. Radcliffe provides detail on the different electoral systems of South Carolina and Louisiana in 
skills of New York Senator and later Democratic president Martin Van Buren, Jackson won 68 percent of the electoral vote and 56 percent of the popular vote, a figure which would remain unbeaten for the rest of the nineteenth century. ${ }^{19}$

Jackson's two term presidency was typified by fidelity to majoritarian thinking. His conflicts with the Bank of the United States, John C. Calhoun and the 'Trail of Tears' inflicted on the Creek and Cherokee tribes relied on what Feller summarizes as the "broader, compelling appeal of the Jacksonian movement", which was connected "not to any line of policy, but to the overriding principle of popular control of government itself." ${ }^{20}$ In the first instance, Jackson's animus towards the President of the Second Bank of the United States, Nicholas Biddle, prioritized populistic sentiment. Matthew Bevan, one of the directors of the Second BUS, reported to Biddle in November 1829 that Jackson had described the bank "as a blessing to the country, administered as it was, diffusing a healthfull circulation, sustaining the political credit without partiality of political bias". ${ }^{21}$ What drove Jackson's opposition to the re-chartering of Biddle's bank in 1832 derived from what Govan outlines as the president's antipathy to "financial oligarchy" and a fidelity to the "Jeffersonian tradition", interests greater than "discontent with the existing credit structure" or "any act of commission or omission by the institution itself". 22

Jackson's policies towards Native American tribes in the Southeastern United States similarly targeted dissenters against the Jeffersonian ideal of a geographically and socially mobile white male citizenry. They also indicated the former general's majoritarian brand of politics. Wilentz notes how Jackson perceived the "Cherokees' demand for full tribal sovereignty" as precipitant of "an irregular nation within a nation" and "a potential threat to national integrity and security". ${ }^{23}$ Pessen likewise summarizes Jackson's view that the tribes of Cherokees, Choctaws, and Chickasaws should not

1824; Wilentz notes that Jackson won " 42 percent of the vote in the eighteen states that allowed voters to choose presidential electors". Wilentz, The Rise of American Democracy, 250.

19 Wilentz, The Rise of American Democracy, 309.

20 Feller, The Jacksonian Promise, 74.

21 Matthew L. Bevan, 1729, quoted in Thomas P. Govan, "Fundamental Issues of the Bank War," The Pennsylvania Magazine of History and Biography 82, no. 3 (July 1958): 305.

22 Govan, "Fundamental Issues of the Bank War," 311.

23 Wilentz, Andrew Jackson: The American Presidency Series, 69. 
be "treated as sovereign nations". ${ }^{24}$ In engineering the white acquisition of their lands, Jackson's "performance was not that of responsible government official (sic) deferring to the will of his constituents.... but rather that of a zealot who fully shared their biases and rapacity." 25

What most underlined the comprehensiveness of Jackson's majoritarianism, however, was his reaction to the nullification crisis of 1832-33. The cause of this crisis can be attributed to the state legislature of South Carolina, which declared the federal tariffs of 1828 and 1832 invalid and passed "an ordinance of nullification" in November of the latter year. ${ }^{26}$ Jackson, despite his upbringing in the Carolinas and strong Southern base of support, notably did not seek rapprochement with South Carolina's nullifiers. Neither did he find the pretext for nullification warranted its destabilization of majoritarian democracy. ${ }^{27}$ Jackson's Force bill, an act which deemed that federal troops could be sent to South Carolina if the state refused to comply with the law, had major realigning effects. Wilentz details how John C. Calhoun, previously Vice President in Jackson's first term but in 1833 a supporter of the nullifiers, castigated the Jackson administration for the issuance of an "imperial edict" and the imposition of "military despotism." 28 Feller comments how the formation of the Whig Party took advantage of the "executive tyranny" and "strident nationalism" which "affronted southern-rights extremists in and out of South Carolina." 29

Withstanding these controversies, Jackson's political vision remained pervasive through the remainder of the antebellum era. As a candidate for president in 1840, the Whig William Henry Harrison emulated Jackson through an "imitation of the Jackson Democrats' 'common man' approach" and a campaign which featured "religious revival, folk festival, and mass entertainment." 30 James Polk furthered the expansionism borne by the Trail of Tears through the annexation of Texas and the Mexican-American War. ${ }^{31}$

24 Edward Pessen, Jacksonian America: Society, Personality and Politics: Revised Edition (Homeword, Illinois: The Dorsey Press, 1978), 297.

25 Ibid, 297.

26 Donald J. Ratcliffe, "The Nullification Crisis, Southern Discontents, and the American Political Process," American Nineteenth Century History 1, no. 2 (2000): 1.

27 Feller, The Jacksonian Promise, 164.

28 Wilentz, The Rise of American Democracy, 385.

29 Feller, The Jacksonian Promise, 186.

30 Ronald P. Formisano, "The New Political History and the Election of 1840," The Journal of Interdisciplinary History 23, no. 4 (Spring 1993): 661.

31 Skowronek, The Politics Presidents Make, 170-74. 
The unsuccessful presidency of Franklin Pierce, to the political theorist Stephen Skowronek, capped a generation of "Jacksonian leadership", which "contrasts with the politics of the patrician period" and reflects a "strengthening of the presidential office." 32

Although the Civil War ended the Jacksonian epoch, tropes and invocations of Jackson continued in the postbellum US. The accidental president Andrew Johnson's humble beginnings in North Carolina and adolescent migration to Tennessee resembled Jackson's own life and political trajectory. ${ }^{33}$ William Jennings Bryan, the Democratic presidential candidate of 1896 who campaigned against the gold standard, was compared to Jackson by Democratic Illinois governor John Peter Altgeld. ${ }^{34}$ Theodore Roosevelt justified his expansion of the presidential office as part of the "LincolnJackson" tradition of power, a continuum which suggested the latter's shibboleth of a strong executive. ${ }^{35}$

The Jacksonian's heterogeneity and its bipartisan imprimatur resonate in various intellectual appraisals of Jackson's political influence. The foreword to Arthur Schlesinger Jr.'s 1945 book The Age of Jackson emphasizes affinity between the "democratic ambiguities" of the "issues, political and economic, of Jackson's day" and their relevance for the "world crisis" of the Second World War, which "has given new urgency to the question of the 'meaning' of democracy." ${ }^{36}$ Schlesinger's quoting of FDR, who acknowledged Jackson's "unending contribution to the vitality of our democracy", connotes a through line which connects the white male enfranchisement of Jackson's time with the New Deal. ${ }^{37}$

Wilentz detects a similar progressivism in Jackson's presidential heritage. His 2005 biography of Jackson dismisses the possible perception that Jackson, "a military hero with populist appeal", can be considered a conservative "forerunner of Ronald Reagan and George W. Bush". ${ }^{38}$ Jackson's opposition "to a small elite of monied men who enjoyed disproportionate

32 Ibid, 129.

33 James D. Barber, “Adult Identity and Presidential Style: The Rhetorical Emphasis,” Daedalus 97, no. 3, Philosophers and Kings: Studies in Leadership (Summer 1968): 951.

34 Jeff Taylor, Where Did the Party Go?: William Jennings Bryan, Hubert Humphrey, and The Jeffersonian Legacy (Columbia, Missouri: University of Missouri Press, 2006): 58.

35 H.W. Brands, T.R.: The Last Romantic (New York: Basic Books, 1997): 422.

36 Arthur Schlesinger Jr., The Age of Jackson (London: Eyre \& Spottiswoode, 1945), xviii-xx.

37 Franklin Delano Roosevelt, quoted in Schlesinger Jr., The Age of Jackson, xx.

38 Wilentz, Andrew Jackson: The American Presidency, 4. 
political power" overlapped with "the overarching aims of American liberalism since the New Deal." ${ }^{39}$ Wilentz' The Rise of American Democracy additionally cautions against reading Jackson as an icon of states' rights conservatism. This work, published also in 2005, cites parallels between Lincoln's reaction to Fort Sumter's assault and Jackson's actions during the nullification crisis, contending that Lincoln turned to "Jackson's doctrine for guidance." 40

Walter Mead, contrastingly, evaluates Jackson's legacy as assimilated within a strain of modern conservatism. Principally locating the Jacksonian within diplomacy, Mead's 2001 book Special Providence: American Foreign Policy and How it Changed the World posits that the 'Jacksonian' sits alongside three other 'schools' of US statecraft: the 'Hamiltonian', a philosophy orientated around the interests of the American business class; the 'Wilsonian', a school of multilateralism indebted to a "missionary" tradition in the nineteenth century; 'the Jeffersonian', an isolationalism based on the founding father and president Thomas Jefferson. ${ }^{41}$ The 'Jacksonian' distinguished itself from these other schools through its pugnacious realism in foreign policy, typified by a "warrior culture" and a "political force that under certain circumstances demands war, supports the use of force and urges political leaders to stop wasting time with negotiations". ${ }^{42}$

Mead's understanding of the Jacksonian, however, also draws on domestic characteristics. Special Providence postulates that Jackson's governance, which helped form "a community of political feeling", finds modern expression in attitudes "suspicious of untrammeled federal power, skeptical about the prospects for domestic and foreign do-gooding" and "opposed to federal taxes but obstinately fond of federal programs seen as primarily helping the middle class". ${ }^{43}$ This cognitive dissonance manifested in a Jacksonianism "that is no longer rural or exclusively nativist" and emblematized by the "modest suburban lawn" rather than the "homesteading farmer". ${ }^{44}$ According to Mead, this domestication has been complemented by an acceptance of groups previously "excluded" by the "Jacksonian com-

39 Ibid, 5.

40 Wilentz, The Rise of American Democracy, 389.

41 For accounts of the Wilsonian's descent from a "missionary tradition": Walter Russell Mead, Special Providence: American Foreign Policy And How It Changed the World (New York: Routledge, 2001), 151.

42 Ibid, 223.

43 Ibid, 224.

44 Ibid, 230. 
munity", including "Mexicans, Asians" and "African Americans". ${ }^{45}$ The author contends that "the bulk of northern and southern Jacksonian opinion is steadily, if not always rapidly, moving to recognize the right of people of all colors and backgrounds". ${ }^{46}$

This assimilationism synergizes with Special Providence's hypothesis that the US has benefitted from a "kaleidoscope" of foreign policy, "which matched the representative nature of American society". ${ }^{47}$ The Jacksonian, in concert with the Wilsonian, Hamiltonian and Jeffersonian schools, could "speak for different interests" and foster "continuities of purpose." 48 As demonstrated in the next section, Trump fits aspects of the Jacksonian foreign policy but complicates the kaleidoscopic dynamics cited by Mead and inverts Jackson's original majoritarian emphasis, departing in multiple ways from various intellectual and historical paradigms.

\section{Trump's relationship with the Jacksonian}

Not unlike Jackson's exploitation of the Democratic-Republican schisms in the 1820s, Trump seized on a collapsing consensus in his campaign for the Republican Party's nomination. Memories of the tests wrought on conservatism by the nation-building and financial bailouts of George W. Bush's presidency, resembling the apostasies from Jeffersonian Republicanism under Presidents Madison and Monroe, enabled Trump to market nationalistic policies which spoke to the Jacksonian diplomacy elucidated by Mead. At the same time, Trump's worldview undercut the kaleidoscope premise of Mead's 'schools' by foregrounding opposition to the Hamiltonian and Wilsonian approaches. On June 16th, 2015, the day Trump announced his presidential run, he lamented NAFTA's integration of Mexico, who were "beating us economically". ${ }^{49}$ The future president also implicitly blamed the interventionist agendas of previous administrations for the "destabilization of the Middle East" and the calamity of "thousands and thousands of wounded soldiers." 50

45 Ibid, 236.

46 Ibid, 237.

47 Ibid, 95.

48 Ibid, 95.

49 Donald Trump, "Presidential Announcement Speech," Time Magazine, June 16, 2015, https://time. com/3923128/donald-trump-announcement-speech/.

50 Ibid. 
Perhaps the foundation of Trump's populist upsurge against Republican Party elites is best understood by looking at the changing perceptions of Francis Fukuyama, the former neoconservative who coined the term the 'end of history' and hypothesized a future of global democracy at the Cold War's close in 1991. Fifteen years later in 2006, Fukuyama, through the reading and application of Mead's diplomatic schools, realized that his 1991 vision of Wilsonian preponderance had been cancelled out in the US by the repulsion of Jacksonian America. Fukuyama, implying that the kaleidoscopic interplay explicated in Special Providence no longer correlated with successful statecraft, argued that the difficulties of democratizing Iraq had ended an "alliance of neoconservatives and Jacksonian nationalists, who for different reasons accepted the logic of regime change in Baghdad". ${ }^{51}$ This divorce stemmed from the alienation of "red state Americans whose sons and daughters are the ones fighting and dying in the Middle East", an injustice which pushed them "back toward a more isolationist foreign policy". ${ }^{52}$ Trump's victory in 2016 ten years later crystallized what Fukuyama called "the unravelling of the liberal world order" and the abandonment of an "overclaimed commitment to the spread of openness and democracy", instead connoting "an assertive and yet more insular politics". ${ }^{3}$

Jackson's ascent to the presidency also broke with the ecumenical outlooks of preceding regimes; presidents James Monroe and John Quincy Adams had respectively sympathized with the cause of Greek independence against the Ottoman Empire and organized a Pan-American conference to encourage friendship amongst states in the Western hemisphere, intercontinental overtures ignored in Jackson's campaign and obviated in his presidency. ${ }^{54}$ The most significant foreign policy episode under Jackson contrastingly hinged on self-interest and brinksmanship. "Spoliation claims"

51 Francis Fukuyama, After the Neocons: America at the Crossroads (London: Profile Books, 2006), 7-8.

52 Ibid, 183.

53 Francis Fukuyama, “America: the failed state," Prospect Magazine, December 13, 2016, https://www. prospectmagazine.co.uk/magazine/america-the-failed-state-donald-trump.

54 In Monroe's December 1822 State of the Union address, the president observed how the struggle of the Greek populace should produce the great excitement and sympathy in their favor which have been so signally displayed throughout the United States." Infoplease, "State of the Union address: James Monroe (December 3, 1822)," accessed November 30, 2019, https://www.infoplease.com/primary-sources/government/presidential-speeches/state-union-address-james-monroe-december-3-1822; Wilentz outlines how the 1826 Panama conference aroused Southern opposition to a "specter of emancipation" and the "idea that American officials would have to mix as equals with a black Haitian envoy." Wilentz, The Rise of American Democracy, 261. 
left unresolved from French deprivations of American shipping during the Napoleonic Wars spurred a diplomacy oppositional to the idealistic aspects of Jackson's predecessors and which, according to a 1976 article by Robert Charles Thomas, "nearly resulted in a tragic war" ${ }^{55}$ The danger of this arose when Jackson "asked Congress in his famous Message of December 1834 for authorization to make reprisals upon French property should the French Parliament fail to vote an appropriation for reparations in its next session." ${ }^{\text {}}$ Jackson's bolder 1836 recommendation to Congress, which stated that he should be empowered to issue "letters of marque and reprisal against French commerce" drew opposition from "commercial interests", whose livelihoods "would be jeopardized in the event of war." 57

Like Jackson's dealings with the French, Trump's political instincts seem to harness a realism which favor American pride over international stability. Trump's complaints over American funding of NATO initially incentivized what Benjamin Schreer describes as a "European strategic autonomy from the US", drifts catalyzed by Trump's derision of "European allies, specifically Germany, for their low levels of defence spending". ${ }^{58}$ The Jacksonian animosity towards the cosmopolitanism of John Quincy Adams and the Panama conference's gestures of hemispheric solidarity finds its echo in Trump's campaign refusal to uphold Article 5 of Nato, the cornerstone principle that an attack on one member warrants the collective action of all members. In a July 2016 interview in which the then presidential candidate was asked about whether the Baltic states could count on the United States "to come to their military aid if they were attacked by Russia", Trump made it clear that his administration would only respond if they have "fulfilled their obligations to us", a quintessentially Jacksonian emphasis on self-reliance and independence adapted for transatlantic relations. ${ }^{59}$

Withstanding this unilateralism, there are discernible disconnects between Trump's Jacksonian campaign postures and the ideologically mercu-

55 Robert Charles Thomas, “Andrew Jackson Versus France American Policy toward France, 1834-36," Tennessee Historical Quarterly 35, no. 1 (Spring 1976): 64.

56 Ibid, 51.

57 Ibid, 64.

58 Benjamin Schreer, “Trump, Nato and the Future of Europe's Defence," The RUSI Journal 164 (April 2019): 10 .

59 Donald Trump, quoted in David E. Sanger and Maggie Haberman, "Donald Trump sets condition for defending NATO allies against attack," The New York Times, July 21, 2016, https://www.nytimes. com/2016/07/22/us/politics/donald-trump-foreign-policy-interview.html. 
rial reality of his presidency. Paul McDonald and Joseph Parent point out in a December 2019 Foreign Affairs article that US troop numbers overseas have been "roughly equivalent to the number Trump inherited" ${ }^{60}$ The fact that Trump has placed an additional 1000 troops in Poland and engaged "in talks to build a permanent military base there" proves that the president's rhetoric is occasionally at odds with the policies of his administration. ${ }^{61}$ Such dissonance qualifies the argument of Michael Clark and Anthony Rickett's 2017 article "Donald Trump and American foreign policy: The return of the Jacksonian tradition", which contends that Trump indicates "the recrudescence of the influence of the Jacksonian tradition", a process thought to be reflected by the president's unilateral policies towards NATO and key US allies. ${ }^{62}$ The capriciousness of Trump's diplomacy has compromised his fidelity to what Clark and Rickett describe as "the core tenets of the Jacksonian tradition" and weakened his repudiation of Clinton's "archetypal liberal internationalist platform", which "afforded primacy to the role of democracy, free-market capitalism, traditional security alliances, and the export of American ideas and norms." 63

There are additional attitudinal, legislative and electoral examples of Trump contravening the principles of Jacksonianisms, historical and modern. His mockery of prior Republican presidential candidate John McCain's war record and dismissal of his experience as a POW in Vietnam, present from the early stages of his primary campaign in 2015, illustrated an irreverence alien to the patriotic culture which treasured the national unity resultant from Jackson's triumph in the Battle of New Orleans. Such armchair impertinence further undermined the conception of the Jacksonian's 'soldierly' qualities provided by Mead. In Special Providence: American Foreign Policy and How it Changed the World, which was published in 2001, Mead posited that McCain's endorsement of "the option of ground troops" in the 1999 Kosovo War derived from an "honor code" which taught Jacksonians that "fighting is honorable". ${ }^{64}$ Trump's attitudinal qualities have

60 Paul K. MacDonald and Joseph M. Parent, “Trump Didn’t Shrink U.S. Military Commitments Abroad-

He Expanded Them", Foreign Affairs, December 3, 2019, https://www.foreignaffairs.com/articles/2019-12-03/ trump-didnt-shrink-us-military-commitments-abroad-he-expanded-them.

61 Ibid.

62 Michael Clark and Anthony Rickett, "Donald Trump and American foreign policy: The return of the Jacksonian tradition," Comparative Strategy 36, no. 4 (2017): 372.

63 Ibid, 370-73.

64 Mead, Special Providence, 251. 
denigrated this Jacksonian tenet. His unabashed avoidance of the Vietnam War's draft, a shamelessness exacerbated by his description of his dating life as "my own personal Vietnam" in the 1990s, highlight that the Jacksonian label has become increasingly arbitrary, liable to fall on anyone who flirts with its nationalistic shibboleths. ${ }^{65}$ Conspiratorial suspicion of the 'deep state', a concept attributed by Jon D. Michaels to a misguided conviction that there are "shadowy elites in the military and government ministries", is one facet of Trump's presidency which overlaps more with Mead's isolationist Jeffersonian school. ${ }^{66}$ This school stressed "qualitative as well as quantative restrictions on U.S. military and diplomatic establishments." ${ }^{67}$

If interpreted as emblematic of a modern Jacksonianism, Trump's political trajectory jars with Special Providence's position that Jackson's values have become gradually non-discriminatory and part of a civic, rather than exclusionary, nationalism. Mead's 2001 claim that Jacksonian America has become more accepting "of all colors and backgrounds" fails to reconcile with a campaign that blamed Mexico for "beating us economically" and warned of the collective danger of migration from "South and Latin America" and "the Middle East." 68 A November 2016 article by Mead repeats Special Providence's observation by commenting that "Jacksonian America today is much more open to nonwhite and non-Anglo cultures", but declines to relate Trump to this shift. ${ }^{69}$

The question of whether Trump poses a revival of Jackson's original ideology and racism, an issue not addressed by Mead, is confronted by Wilentz. The author of The Rise of American Democracy describes analogies between Trump and Jackson "as flawed to the point of absurdity" as the latter "warned against an earlier version of the swindler capitalism that Trump embodies and celebrates."70 Wilentz also retorts that Trump's political agenda is "more Calhoun than Old Hickory" (Jackson's sobriquet), be-

65 Donald Trump, quoted in Michael Kruse, "How Vietnam Became Donald Trump's Forever War," Politico, February 26, 2019, https://www.politico.com/magazine/story/2019/02/26/vietnam-donald-trump-foreverwar-225210.

66 John D. Michaels, “Trump and the 'Deep State': The Government Strikes Back,” Foreign Affairs 96, no. 5 (2017): 52 .

67 Mead, Special Providence, 194.

68 Mead, Special Providence, 237; Time Magazine, "Here's Donald Trump's Presidential Announcement Speech,” June 16, 2015, https://time.com/3923128/donald-trump-announcement-speech/.

69 Mead, "Donald Trump's Jacksonian Revolt."

70 Sean Wilentz, "No, There Is No Precedent," Democracy: A Journal Of Ideas 46 (Fall 2017): https://democracyjournal.org/magazine/46/no-there-is-no-precedent/. 
cause it "seeks to narrow the citizenry through unsubtle voter suppression" and "demonizes the federal government". ${ }^{71}$

Trump's most significant departure from Jacksonianism, however, is not attitudinal or ideological, but electoral. As was mentioned in the introduction, the 2016 election was mythologized by Bacevich as redolent of Jackson's ousting of John Quincy Adams in 1828. But Trump's election victory in fact possessed closer resemblance to the outcome which infuriated Jackson's followers in 1824. Clinton's lead in the popular vote over Trump, which totaled almost three million, qualified categorizations of Trump as an heir to what Sellers cites as the "modern presidential politics" which "originated with the majority that claimed a democratic victory for Jackson in 1824."72 The disparity established by Trump's simultaneous lead in the Electoral College conjured comparisons with other perverse election outcomes besides 1824. These included the compromises which secured Republican Rutherford B. Hayes the White House in the aftermath of 1876, the precarious triumph of Benjamin Harrison in 1888 and the 2000 election which brought George W. Bush to power. ${ }^{73}$ More recently, the impeachment of Donald Trump by the House of Representatives has prompted journalists to make parallels with Andrew Johnson, a postbellum president who attempted to assemble a coalition of Northern Democrats and white southerners against overwhelming Republican congressional majorities. ${ }^{74}$

A look at the results of individual states in the 2016 election yields historic ironies when considering Trump's framing as part of a populist lineage. Nevada and Colorado, two Western states which backed William Jennings Bryan in his three unsuccessful presidential campaigns, voted for Clinton.

71 Sean Wilentz, "What We Saw as Trump took Office," The New York Times, January 20, 2017, https://www. nytimes.com/interactive/projects/cp/opinion/presidential-inauguration-2017/history-trump-more-johncalhoun-than-andrew-jackson.

72 For information on the disjunction between the popular and electoral vote in the 2016 election: Drew Desilver, "Trump's victory another example of how Electoral College wins are bigger than popular vote ones," Pew Research Center, December 20, 2016, https://www.pewresearch.org/fact-tank/2016/12/20/ why-electoral-college-landslides-are-easier-to-win-than-popular-vote-ones/; Charles Sellers, The Market Revolution: Jacksonian America, 1815-1846 (New York: Oxford University Press, 1991), 200.

73 Tara Law, "These Presidents Won the Electoral College - But Not the Popular Vote," Time Magazine, May 15, 2019, https://time.com/5579161/presidents-elected-electoral-college/.

74 For a journalistic comparison between Trump and Andrew Johnson: Tim Murphy, "Trump's Not Richard Nixon. He's Andrew Johnson," Mother Jones, accessed January 9, 2020, https://www.motherjones.com/ politics/2019/12/trumps-not-richard-nixon-hes-andrew-johnson/; For information on Andrew Johnson's political coalition: Martin E. Mandell, Johnson, Grant and the Politics of Reconstruction (New York: Columbia University Press, 1973), 17. 
Most states in the Upper Midwest meanwhile, a section of the United States which had supported the anti-populist William McKinley against Bryan in 1896 and 1900, were crucial to Trump's ascent to the Oval Office. ${ }^{75}$ Trump's electoral coalition hence recapitulates elements of the industrial and protectionist support which sustained the Republican Party throughout the late nineteenth century, an affinity which had been latterly supplanted by the late twentieth century emergence of the Sunbelt.

Whilst the Midwestern states fundamental to Trump's victory point to a new political geography for American populism, declining electoral influence elsewhere underlines the minoritarianism and precariousness which must qualify considerations of Trump as a legatee of Jacksonian America. Trump's presidency is undergirded by a body of support less comprehensive than that of Reagan, who Peter Dueck argued in 2012 represented "the definitive triumph of the GOP's Jacksonian wing." "76 Dueck posited that Reagan epitomized the Republican Party's shift from "an anti-interventionist, Jeffersonian Party at heart, based in the old Midwest, to a hawkish, Jacksonian one, centred above all in the nation's Sunbelt."77

Trump's recapturing of the Republican Party's ancestral heartlands, along with his diminishing returns in states which typified the Reagan cultivation of the Sunbelt, reverted this orientation. Having an immense popularity with older white and non-college educated voters enabled Trump to win five Midwestern states previously won twice by Obama and the Southern states of Florida and North Carolina. ${ }^{78}$ Yet swings to Clinton in the two most populous states, the safe blue state of California and the traditionally red state of Texas, attested to Republican declines in two Sunbelt states won twice by Reagan, Trump's reliance on the Electoral College and a maldistribution of Democratic votes. ${ }^{79}$ The bitter fruits of the Republican retrench-

75 This article provides a map of states which indicates how McKinley dominated the Great Lakes region in 1896 and won states such as Michigan and Wisconsin: Andrew Gelman, "The Twentieth-Century Reversal: How Did the Republican States Switch to the Democrats and Vice Versa?", Statistics and Public Policy 1, no. 1 (December 2014): 2.

76 Peter Dueck, “Jacksonian Republicans," United States Studies Centre, February 23, 2012, https://www. ussc.edu.au/analysis/jacksonian-republicans.

77 Ibid.

78 William H. Frey, "The demographic blowback that elected Donald Trump," Brookings Institute, November 10, 2016, https://www.brookings.edu/blog/the-avenue/2016/11/10/the-demographic-blowback-thatelected-donald-trump/.

79 Adrian Beaumont, "US election final results: how Trump won," The Conversation, December 17, 2016, https://theconversation.com/us-2016-election-final-results-how-trump-won-69356. 
ment from the Sunbelt only became clear in the 2018 midterm elections, when the former house seat of George H.W. Bush in the Seventh Congressional District of Texas was lost to the Democratic Party alongside other totemic constituencies. ${ }^{80}$

In contrast, Reagan's success in the Sunbelt epicenter was less adjoined with precipitous losses in the Midwest. Reagan's forty-four state landslide in 1980 coincided with the defeats of prominent Democratic Senators in Indiana, Iowa and Wisconsin. ${ }^{81}$ In 1984, the only Midwestern state Reagan lost was Minnesota, the Democratic nominee Walter Mondale's home state. $^{82}$ The 'blue wall' of states taken by Trump had only started to lean towards the Democratic Party on the presidential level since the 1988 election, when Michael Dukakis added Wisconsin and Iowa to his meagre total of states. ${ }^{83}$

On the other hand, despite the asynchronous dynamics of his 2016 election performance, Trump's disproportionate support amongst white working-class men in what Francis categorizes as the regions of the "upper Rockies, Midwest and Appalachia" has perhaps calcified Jacksonian identity in a fashion more tangible than the majoritarian authority enjoyed by Reagan. ${ }^{84}$ Trump's landslide losses on the coasts and dominance in states such as West Virginia, a contemporary Republican bastion in presidential elections which had mostly voted Democrat in the latter part of the $20^{\text {th }}$ Century, underscored Trump's dramatic hold over white blue-collar America. ${ }^{85}$ The migration of suburbanites and college educated voters to the Democratic Party has further focalized the GOP as the party of white laboring men, the exact electoral demographic brought to prominence by Andrew Jackson.

80 David Frum, "There Is No Progressive Majority in America," The Atlantic, November 14, 2018, https://www.theatlantic.com/ideas/archive/2018/11/what-midterms-showed-about-progressive-candidates $/ 575899 /$.

81 Douglas A. Hibbs Jr., "President Reagan's Mandate From The 1980 Elections," American Politics Quarterly 10, no. 4 (October 1982): 388.

82 Howell Raines, "Reagan Wins By a Landslide, Sweeping at Least 48 States; G.O.P. Gains Strength in House," The New York Times, November 7, 1984, https://www.nytimes.com/1984/11/07/ politics/reaganwins-by-a-landslide-sweeping-at-least-48-states-gop-gains.html.

83 Sean Trende \& David Byler, "How Trump Won: The Midwest," RealClear Politics, January 17, 2017, https://www.realclearpolitics.com/articles/2017/01/19/how_trump_won_the_midwest_132834.html.

84 Robert D. Francis, "Him, Not Her: Why Working-Class White Men Reluctant about Trump Still Made Him President of the United States," SOCIUS Special Collection: Gender \& Politics 4 (2018): 1.

85 Dante Chinni and Matt Rivera, "West Virginia: How the Bluest State Became the Reddest," NBCnews, December 18, 2016, https://www.nbcnews.com/meet-the-press/west-virginia-how-bluest-state-becamereddest-n697491. 
The fact that this group today wields far less electoral influence than under Jackson has been central to the minoritarian dimension of Trumpism and has helped bolster conservative support with the fear of liberal hegemony. This fear suffused an article published initially anonymously by a conservative author in the build-up to the 2016 election. The author described the coming contest as "the Flight 93 election" because Hillary Clinton threatened "Russian roulette with a semi-auto" to Republican America while "with Trump, at least you can spin the cylinder and take your chances." ${ }^{86}$ Coarse claims surrounding "the ceaseless importation of Third World foreigners" by Democratic administrations hypothesized a future electorate "more left... with every cycle" and a "permanent electoral majority" for "the Left and the Democrats". ${ }^{87}$

Similar warnings of eradication often permeate Trump's speeches and showcase an unwillingness to solicit alternative votes. An August 2016 address by the then Republican nominee to a conservative audience in Arizona listed the dangers to working class communities wrought by "amnesty, open borders and low wages." 88 Looking to consolidate the Jacksonian base rather than expand it, such rhetoric contravened the Republican National Committee's 'autopsy' report on Mitt Romney's loss in the 2012 election and its call for "more inclusion" of "Hispanic, black, Asian and gay Americans". ${ }^{89}$ This focus on the 'base' means that comparisons of Trump's electoral breakthrough with the majority vote for Brexit in the UK's 2016 EU referendum ignore the reality of what the journalist Greg Sargent labels "minoritarian populism", a phenomenon crystallized in the Republican Party's "partisan gerrymandering, voter-suppression and census-gaming". ${ }^{90}$ The 'depth over breadth' quality of Trump's relatively invariable approval rating, which remained between thirty-six and forty-five percent from January 2017 to March 2019 according to FiveThirtyEight's data, moreover re-

86 Publius Decius Mus, “The Flight 93 Election,” Claremont Review of Books, September 5, 2016, https:// claremontreviewofbooks.com/digital/the-flight-93-election/.

87 Ibid.

88 Donald Trump, Full text: Donald Trump immigration speech in Arizona," Politico, August 31, 2016, https://www.politico.com/story/2016/08/donald-trump-immigration-address-transcript-227614.

89 Reince Preibus, quoted in Shushannah Walshe, "RNC Completes 'Autopsy' on 2012 Loss, Calls for Inclusion Not Policy Changes," ABC News, March 18, 2013, https://abcnews.go.com/Politics/OTUS/rnccompletes-autopsy-2012-loss-calls-inclusion-policy/story?id=18755809.

90 Greg Sargent, "Trump and the problem of 'minoritarian populism'," The Washington Post, October 30, 2019, https:/www.washingtonpost.com/opinions/2019/10/30/trump-problem-minoritarian-populism/. 
flect his popularity amongst a substantial, if no longer dominant, segment of the US populace. ${ }^{91}$

In conclusion, examination of the Jacksonian in the context of Trump's presidency reveals the need for firmer definitions of the governing philosophy which originated with America's seventh president. Emergent political figures, however outwardly 'Jacksonian', are unlikely to align with all the facets of Jackson's presidency. Future analyses should adopt more specificity by categorizing according to whether politicians fit either the economic vision, diplomatic approach or cultural underpinnings of the Jacksonian.

Trump, an example of a president who requires nuanced cataloguing, shows obvious disconnects with the attitudinal and ideological approach intellectually canonized by authors such as Schlesinger, Wilentz and Mead. The most significant fissure, however, lies in the electoral. Impressions of Trump as an apotheosis of Jacksonianism fail to acknowledge the minoritarian foundation of his presidency and the Republican Party's reliance on a voting bloc lacking the preeminence of Jackson's epoch. The hypocritical majoritarianism of Andrew Jackson's tenure has been laid bare by historians who have examined the prohibition of "antislavery mailings" to the South in appeasement of "southern minorities" or the denials of enfranchisement to women and Native Americans. ${ }^{92}$ Yet the electoral precariousness of Trumpism more closely resembles the post-Civil War presidencies of Andrew Johnson and Rutherford B. Hayes, a lineage which will be reinforced if the 2020 presidential election repeats an inverse correlation between the popular and electoral vote or climaxes in Republican loss.

91 Geoffrey Skelley, “Trump's Approval Rating Is Incredibly Steady. Is That Weird Or The New Normal?”, FiveThirtyEight, March 28 2019, https://fivethirtyeight.com/features/trumps-approval-rating-is-incredibly-steady-is-that-weird-or-the-new-normal/.

92 William W. Freehling, The Road to Disunion: Volume I: Secessionists at Bay, 1776-1854 (New York: Oxford University Press), 309. 
